\title{
Clinical trial of 4 month chemotherapy regimen in tuberculous pleural effusion
}

\author{
A.K. Janmeja, B. Ray, N.K. Jhamb, B. Arora
}

\begin{abstract}
Abstrak
Penelitian ini bertujuan untuk menguji apakah pemberian kemoterapi untuk efusi pleura tbc dapat dipersingkat menjadi 4 bulan. Lima puluh penderita efusi pleura positif tbc diberi paduan $2 S H R Z / 2 H R$ selama empat bulan. Empat puluh lima dari pasien ini menyelesaikan pengobatan, dan semuanya menunjukkan hasil yang sangat baik, yaitu pengurangan gejala dan cairan pleura secara cepat tanpa kegagalan pengobatan. Empat puluh dua pasien berhasil diamati selama satu setengah tahun berikutnya, dan tidak satupun yang kambuh. Gejala sisa berupa penebalan pleura satu sisi dan nyeri dada ringan dialami oleh 4 pasien, bahkan sampai satu setengah tahun setelah pengobatan selesai. Dari hasil tersebut disimpulkan bahwa terapi jangka pendek selama 4 bulan memberikan hasil sangat baik pada pengobatan efusi pleura tbc.
\end{abstract}

\begin{abstract}
The study was conducted with the main objective to find out whether the chemotherapy duration can be reduced to four months in the treatment of tuberculous pleural effusion. Four month chemotherapy regimen 2 SHRZ/2HR was given to 50 confirmed fresh cases of tuberculous pleural effusion. Only 45 patients could complete total duration of chemotherapy. However all of them showed excellent response in term of rapid resolution of pleural effusion and fast amelioration of symptoms without any failure. Out of these 45 patients subjected to a follow up of one and a half year, 42 completed it and none of them relapsed. Sequelae in the form of ipsilateral thickened pleurae and mild chest pain persisted in 4 cases even one and a half year after completion of chemotherapy. Thus, it is concluded that four month short course chemotherapy was highly successful in the treatment of tuberculous pleural effusion.
\end{abstract}

Keywords : Tuberculosis, pleural effusion, paucibacillary pulmonary puberculosis, chemotherapy, ultra short chemotherapy for pleural effusion

\section{INTRODUCTION}

At present, we have many highly efficient standard chemotherapy (CT) regimens of 6-9 months duration for treatment of pulmonary tuberculosis. Although duration has been reduced but the patient compliance has not improved proportionately, which still remains around $50 \%$. $^{1,2}$ Therefore search is on to find out still shorter duration efficient CT regimens. Various regimens of less than six months duration have been studied in sputum positive pulmonary tuberculosis but the results were not encouraging as they carried very high relapse rate. ${ }^{3-8}$ However, some of these regimens have been found very effective in treating paucibacillary tuberculosis like smear-negative culture-positive

Department of Chest and Tuberculosis and Department of Pathology, Pt. B.D. Sharma Postgraduate Institute of Medical Sciences, Rohtak, India or smear and culture-negative pulmonary tuberculosis. ${ }^{9,10}$ Recently various trials with 4 months CT regimens in such cases have found high cure rate with only $1-3 \%$ relapse rate and thus have proved the above view point. 11,12

Tuberculous pleural effusion (PE) is basically an extension of primary complex in which peripheral Ghon's focus or enlarged hilar lymph node erodes in pleural cavity and tubercle bacilli get discharged over pleural surface leading to tuberculous pleurisy, although sometimes spread could be hematogenous or lymphatics. There is very minimal pulmonary lesion and tubercle bacilli are rarely isolated from pleural fluid or sputum of such patients and thus, beyond doubt it is a paucibacillary tuberculosis. ${ }^{13}$ Therefore we planned this study with the main objective to find out whether four months short course chemotherapy will be adequate in tuberculous pleural effusion cases. 


\section{METHODS}

\section{Patients}

The cases were selected from outpatients in the Department of Chest and Tuberculosis Unit of PGIMS, Rohtak, during the period of January to June 1994. The main presenting symptoms were fever, chest pain, dry cough, exertional dyspnoea, anorexia and vomiting.

A total of 72 cases of P.E. was initially investigated and from those, 50 confirmed tuberculous P.E. cases were obtained. Criteria for exclusion were: age less than 15 years, complicated P.E., concomitant lung lesion, sputum positive for Acid-Fast- Bacilli (AFB) and associated problems like diabetes mellitus, hypertension, COPD, pregnancy, bronchiectasis, lung carcinoma. Apart from routine blood and urine investigations the patients were subjected to $\mathrm{X}$-ray chest $P A$ view, liver function tests and detailed pleural fluid examination for AFB by smear and culture, for pyogenic organisms, biochemistry and cytology. Mantoux test was done using one unit of PPD RT 23 tween 80 . Pleural biopsy was done with Cope's biopsy needle taking 3-4 pieces per procedure. In case of inconclusive histopathology report, the repeat biopsy was performed wherever possible. The diagnosis of tuberculous P.E. was made by obtaining typical caseating or non-caseating epithelioid granuloma in pleural biopsy in 41 cases, by culturing tubercle bacilli from pleural fluid in 6 cases, while in three cases fluid culture as well as biopsy both confirmed the diagnosis. The pleural fluid was straw colour exudate with sugar contents ranging $30-60 \mathrm{mg} \%$ and having predominantly lymphocytic cellularity in all the patients.

\section{Treatment}

All the 50 P.E. cases were given four months short course chemotherapy regimen $2 S H R Z / 2 H R$ i.e. streptomycin + isoniazid + rifampicin + pyrazinamide daily for 2 months in intensive phase followed by INH + rifampicin daily for next two months in continuation phase. The daily drug dosages were: streptomycin 0.75-1.0 g IM, isoniazid $300 \mathrm{mg}$ P.O., rifampicin 450$600 \mathrm{mg}$ P.O., pyrazinamide 1.5-2.0 g P.O and ethambutol $15-25 \mathrm{mg} / \mathrm{kg}$ body weight P.O. The patients were treated on domicilliary basis except for initial 1-2 weeks period during which they were hospitalised for detailed investigations.

All the 45 patients who completed $\mathrm{CT}$ were subjected to a follow up of one and half year duration with the objectives viz: (1) to search for recurrence of disease and (2) to observe for any sequelae. The criteria for recurrence were: 1 . clinical signs and symptoms suggestive of active tuberculosis, 2. reaccumulation of pleural fluid, 3. appearance of pulmonary lesion on $\mathrm{X}$-ray and 4. isolation of tubercle bacilli from sputum or pleural fluid. During the follow-up, each patient was called every three months for X-ray chest PA view, sputum examination for tubercle bacilli by smears and culture and clinical evaluation.

\section{RESULTS}

Table 1 reveals the age and sex distribution of these patients. The extent of PE and total duration of illnes are shown in Table 2.

Table 1. Age and sex distribution

\begin{tabular}{lccc}
\hline $\begin{array}{l}\text { Age group } \\
\text { (years) }\end{array}$ & $\begin{array}{l}\text { Male } \\
\text { no.(\%) }\end{array}$ & $\begin{array}{l}\text { Female } \\
\text { no. }(\%)\end{array}$ & $\begin{array}{l}\text { Total } \\
\text { no. }(\%)\end{array}$ \\
\hline $15-20$ & $6(12)$ & $4(8)$ & $10(20)$ \\
$21-40$ & $27(54)$ & $8(16)$ & $35(70)$ \\
$41-60$ & $3(6)$ & $0(0)$ & $3(6)$ \\
$>60$ & $2(4)$ & $0(0)$ & $2(4)$ \\
\hline Total & $38(76)$ & $12(24)$ & $50(100)$ \\
\hline
\end{tabular}

Table 2. Total duration of illness (T.D.I.) and extent of pleural effusion

\begin{tabular}{lrrrrrr}
\hline Extent & \multicolumn{3}{c}{ No.of patients } & \multicolumn{3}{c}{ T.D.I. (days) } \\
\cline { 2 - 7 } $\begin{array}{l}\text { Apty in ml. } \\
\text { Appox.) }\end{array}$ & Total & Unilateral & Bilateral & Mean & SD & SE \\
\hline Minimal (<500) & 12 & 11 & 1 & 49.1 & \pm 39.4 & 11.4 \\
Moderate (500-1000) & 34 & 33 & 1 & 44.0 & \pm 37.7 & 6.5 \\
Massive ( $>1000)$ & 4 & 3 & 1 & 28.7 & \pm 22.5 & 11.2 \\
\hline Total & 50 & 47 & 3 & & & \\
\hline
\end{tabular}

During the course of treatment three out of 50 cases were lost, two after 15 days and one after 2 months. Two patients developed drug induced hepatitis within two weeks of initiation of chemotherapy and were subsequently treated with other than trial regimens, hence were excluded from further evaluation. In four patients, injection of streptomycin had to be substituted with Ethambutol tablet as it resulted within one month of starting marked giddiness and vertigo in three cases; while the forth patient expressed his unwillingness due to severe local pain. Mean period required for resorption of pleural fluid was $15.0 \pm 0.8$ days in cases of massive P.E., $12.0 \pm 1.2$. days in moderate P.E. and $10.0 \pm 3.2$ days in minimal P.E. cases. Thoracocentesis 
was attempted 4-8 times in massive P.E. cases while the procedure was performed for 1-3 times only in majority of moderate and minimal P.E. cases. All patients responded well to the treatment and were asymptomatic on completion of chemotherapy, except five patients who cintinued to have mild ipsilateral chest pain on deep breathing or coughing. Four of these were found to have developed ipsilateral thickened pleura. Out of 45 patients evaluated during follow-up of one and half year, two were lost after 3 months and one after 6 months, thus only 42 patients completed total follow-up. During follow up none of them developed any of criteria already set to label recurrence of disease.

\section{DISCUSSION}

Many clinical trials have shown that 4 months short course chemotherapy (SCCT) regimens in the treatment of smear-negative culture-negative pulmonary tuberculosis are almost as good as the 6 month SCCT regimens. 9,10,12 In Hong Kong, Chest Service/TRC Madras/BMRC trial ${ }^{10}$ with SHRZ thrice weekly or daily for 4 months in smear-negative and culture-positive pulmonary tuberculosis patients, was associated with the relapse rate of only $4 \%$ after 5 years of follow-up. Girling D.J. ${ }^{9}$ obtained $1-3 \%$ relapse with 2SHRZ/2HF regimen in smear-negative culture-negative pulmonary tuberculosis. Dutt et $\mathrm{al}^{12}$ in another trial in similar type of cases obtained only $1-2 \%$ relapse and that too with a relatively less potent regimen i.e. $1 \mathrm{HR} / 3 \mathrm{H}_{2} \mathrm{R}_{2}$, meaning thereby that paucibacillary pulmonary tuberculosis can be managed with 4 months SSCT regimens pretty confidently. Moreover, such regimens are being used routinely to treat culture and smear-negative pulmonary tuberculosis in Hong Kong; ${ }^{11}$ and recently WHO $^{14}$ has also recommended such regimens for category III pulmonary tuberculosis patients. Tuberculous PE is also a paucibacillary disease and hence these 4 months SCCT regimens can possibly be tried in its management.

The results of the present study showed that 4 months chemotherapy with 2 SHRZ/2HR daily regimen in the treatment of tuberculous pleural effusion is highly effective. Our results are in accordance with those of a study in pleural effusion by Dutt et al ${ }^{15}$ which showed that isoniazid plus rifampicin for 6 months without initial pyrazinamide had 1 failure in 162 patients and no relapse over a median follow-up of 46 months. We could obtain comparable good results with the 4 month regimen most likely due to inclusion of pyrazinamide in intensive phase of 2 months which make the com- binations certainly more potent and sterilizing as compared to the regimens without pyrazinamide.

The diagnosis of tuberculous P.E. in the present study was made according to the accepted criteria quoted by Herbert et al ${ }^{16}$ viz: 1 . pleural biopsy demonstrating either caseating or non caseating epithelioid granuloma, 2 . identification of tubercle bacilli in the biopsy specimen, 3 . culture of tubercle bacilli from the pleural fluid or pleural biopsy. Identification of tubercle bacilli in pleural biopsy specimen could not be done due to lack of facility at our centre, therefore histopathology and pleural fluid culture for AFB were mainly used for the diagnosis. Resolution of pleural effusion and fast amelioration of clinical features with antituberculosis drugs in all cases further substantiated the tuberculous etiology in these patients.

The presentation of P.E. could be abrupt or insidious, $88 \%$ of our patients presented with illness of 2-6 months duration while only $12 \%$ had less than a week duration of illness. This is contrast to the findings of Herbert $^{16}$ and Levine ${ }^{17}$ who found acute onset in two third of their cases. Massive P.E. patients reported a bit earlier, probably they became more acutely symptomatic than moderate and minimal P.E. cases (Table 2). None of our patients had pleural fluid eosinophilia confirming the impression that pleural eosinophilia is rare in tuberculosis. Frank serosanguinous fluid was encountered in none except a few RBCs in $14 \%$ cases detected on microscopic examination. Modérately elevated SGOT $(49 \pm 10.8$ to $101.0 \pm$ $1.4 \mathrm{IU})$ in $50 \%$ cases and SGPT $(52.7 \% \pm 14.2$ to 129.5 \pm 3.6 I.U.) in $32 \%$ cases during the early phase of treatment were in no way deterrent to chemotherapy. These enzymes returned to normal within 2 months in all cases. Tuberculin test was negative in $12 \%$ cases emphasizing that negative test does not exclude tuberculous etiology of P.E., the fact already stressed by Kent $^{19}$ and Holden. ${ }^{20}$ Ultrasonographic approximate estimation of pleural fluid quantity was used for categorising the extent of P.E. It was termed moderate when fluid was $500-1000 \mathrm{ml}$, minimal when less thanand massive when more than this quantity as mentioned by Fraserand Pare. ${ }^{18}$

We achieved better treatment completion rate of $90 \%$ inspite of the fact that treatment was on domiciliary basis. This could be attributed to: (1) high degree of motivation in the present trial conditions, (2) shorter duration might have cut down the defaulte rate, (3) patients were psychologically prepared to comply with this ultra short duration regimen and (4) the drug 
toxicity was not a problem. Apart from drug hepatitis in two patients (4\%), 7 patients (14\%) developed minor side effects like gastritis, vomiting, nausea and injection pain locally which were managed symptomaticaly. The reported rate of hepatitis in various 4 months SCCT trials is $0-3 \% .^{21,22}$

During the closely monitored follow-up of one and half years duration, none of the patients relapsed. The only observed significant sequelae was mild thickening of ipsilateral pleurae along with mild chest pain during coughing or deep breathing in $4(8 \%)$ cases. We did not encounter any mortality during the course of whole trial. As far as the treatment cost is taken into account, the 4 months CT regimen is obviously more economical than the standard 6-9 month short course regimen in routine use. In addition, they have additional advantage of avoiding cumulative drug toxicity of another 2-5 months.

We concluded that 4 month CT regimen using 2SHRZ/2HR is highly affective in the treatment of tuberculous P.E. Therefore, it can be emphasized that in tuberculous P.E. without any lung lesion, 4 month short course chemotherapy is adequate.

\section{REFERENCES}

1. Maini VK, Kallan BM, Bhatia AS, Malhotra B and Singh AP. Comparative study of case holding among domicillary versus initially hospitalised patients taking short course chemotherapy. Papers presented at 48th National Conference on Tuberculosis and Chest Disease. Bhopal, 9th to 12 Dec., 1993. Ind J Tub 1994; 41: 186.

2. Arora VK. Short course chemotherapy in tubercular lymphadenitis. Papers presented at 48th National Conference on Tuberculosis and Chest Disease. Bhopal, 9th to 12 Dec., 1993. Ind J Tub 1994; 41: 181.

3. Fox W. Bull. International Union Against Tuber. 1981; 56: 135.

4. Mehrotra ML. Quoted by Fox W. Bull International Union Against Tuber. 1981; 56: 135.

5. Mehrotra RC, Tripathy S.P. Bull International Union Against Tuber. 1981; 57: 21.
6. Hong Kong Chest service/BMRC, Controlled trial of four thrice weekly regimens and a daily regimen all given for 6 months for pulmonary tuberculosis. Lancet 1981; 1: 171-4.

7. Singapore Tuberculosis Service/British Medical Research Council. Clinical trial of 4 month and 6 month Regimens of Chemotherapy in treatment of pulmonary tuberculosis. Am Rev Respir Dis 1979; 119: 579-86.

8. Mehrotra ML. Bull International Union Against Tuber. 1982; 57: 61.

9. Girling DJ. 12th International Conference, Florence 1981.

10. Hong Kong Chest Service/Tuberculosis Research Centre Madras/BMRC Chen W. Proceeding 12th International Conference on Chemotherapy 1981.

11. A controlled trial of 3 month, 4 month and 6 months regimen of chemotherapy for sputum smear negative pulmonary tuberculosis. Am Rev Resp Dis 1989; 139: 871-76.

12. Dutt AK, Dory Moers and William W Stead. Smear and culture negative pulmonary tuberculosis: 4 month short course therapy. Am Rev Resp Dis 1989; 139: 867-70.

13. D de Wit, G Mart feus, L Steyn. A comparative study of polymerase chain reaction and conventional procedure for diagnosis of tuberculosis pleural effusion. Tubercle and Lung Disease 1992; 73: 262-67.

14. Treatment of tuberculosis: Guidelines for National programme. WHO Geneva 1993 in Standardization of short course chemotherapy. $\mathrm{p}-12$.

15. Dutt AK, Moers D, Stead WW. Tuberculous pleural effusion: 6 month therapy with isoniazid and rifampicin. Am Rev Resp Dis 1992; 145: 1429-32.

16. Herbert W. Berger and Ervido Mejia critical review. Tuberculous Pleurisy. Chest 1973; 63.

17. Levine H, Szanto PB et al. Tuberculous pleurisy an acute illness. Arch Intern Med 1968; 122: 329-32.

18. Frater GR \& Pare JA. Roentgenologic signs of diseases of pleura. Diagnosis of diseases of chest. Vol.1 W.B. Saunders Company USA $1970 ;$ pp.347-8.

19. Kent DC, Schwartz R. Active pulmonary tuberculosis with negative tuberculin test. Am Rev Resp Dis 1967; 95: 411-18.

20. Holden M, Dubin MR and Diamond PH. Frequency of negative intermediate strength tuberculin test with active tuberculosis. N Engl Med 1971; 285: 1506-9.

21. Singapore Tuberculosis Service/BMRC Clinical trial of 4 month and 6 month regimen of chemotherapy in treatment of pulmonary tuberculosis. Am Rev Respir Dis. 1979; 110: 579-86.

22. East Africa/BMRC Centre for Clinical trial of SCCT (4-M) regimen in pulmonary tuberculosis. Lancet, 1978; 334-8. 